\title{
RESEARCH PAPER \\ Effect of xylanase, cellulase and natural maguey extract on the chemical composition of corn silage and in vitro rumen gas production
}

\author{
José Ramón Pascual Franco Martínez¹, Andrés González Huertaㄹ, Delfina \\ de Jesús Pérez López ${ }^{1}$, Rodolfo Serrato Cuevas ${ }^{1}$, Abdelfattah Zeidan \\ Mohamed Salem², Lizbeth E. Robles-Jimenez², and Manuel Gonzalez- \\ Ronquillo ${ }^{2}$ \\ ${ }^{1}$ Facultad de Ciencias Agrícolas-Universidad Autónoma del Estado de México, México. \\ ${ }^{2}$ Facultad de Medicina Veterinaria-Universidad Autónoma del Estado de México, México. Instituto \\ Literario 100. Toluca, Estado de Mexico. 50000
}

\begin{abstract}
J.R.P. Franco Martínez, A. González Huerta, D.J. Pérez López, R. Serrato Cuevas, A.Z.M. Salem, L.E. Robles-Jimenez, and M. Gonzalez-Ronquillo. 2020. Effect of xylanase, cellulase and natural maguey extract on the chemical composition of corn silage and in vitro rumen gas production. Int. J. Agric. Nat. Resour. This study considered the application of two exogenous enzymes, xylanase (XYL) and cellulase (CELL), and maguey extract (ME), (applying $1 \mathrm{ml}$ per $\mathrm{kg}$ as fresh matter) and a control (without additive) in four maize silage varieties (San Diego, Cacahuacintle, P-1832 and Victoria), to investigate their effect on the chemical composition (CC), gas production (GP) and in vitro ruminal fermentation. The GP was measured at $0,3,6,9,12,24,36,48,72$ and 96 hours of incubation. Dry matter disappearance (DMD), organic matter disappearance (OMD), metabolizable energy (ME), and short chain fatty acids (SCFAs) were determined after $96 \mathrm{~h}$ of incubation. Data were analyzed using a completely randomized design with a $4 \times 4$ factorial arrangement with three replications. The $\mathrm{CC}$ showed a significant effect $(\mathrm{P}<0.05)$ for varieties with the exception of organic matter $(\mathrm{OM})$, and the inclusion of additives increased the dry matter (DM) and crude protein (CP). A significant effect $(\mathrm{P}<0.01)$ was observed for the varieties in the GP parameters and ruminal fermentation. The addition of XYL, CEL and ME promoted dry matter degradation and increased energy availability, with increased in vitro gas production.
\end{abstract}

Keywords: Additives, enzymes, silage.

\section{Introduction}

Corn silage is most commonly used in dairy cow feed for its energy value and high dry matter (DM). Corn forage is a fibrous feed with high concentrations of cellulose and hemicellulose,

Received May 07, 2019. Accepted Mar 31, 2020.

Corresponding author:mrg@uaemex.mx which can create a structural complex of carbohydrates and lignin to reduce the digestibility of carbohydrates and thereby decrease the efficient utilization of feed by ruminants (Elghandour et al., 2014). Fibrolytic enzymes alter the structure of forages, making them more susceptible to ruminal hydrolysis (Nsereko et al., 2000). Cellulases, on the other hand, cause partial hydrolysis 
of the plant cell wall during ensiling (Kuhad et al., 2011). Settimi et al. (2013) mention that direct application of enzymes to the substrate favors the formation of a stable enzyme-substrate complex, which increases the effectiveness of the exogenous enzymes, improving fiber solubility or availability for microbial attack in the rumen. Exogenous fibrolytic enzymes (EFEs) are most effective when applied in liquid form to food prior to ingestion, as they can help remove structural barriers that limit microbial digestion of the food in the rumen, encouraging the release of soluble carbohydrates (Beauchemin et al., 2004). EFEs such as xylanases and cellulases are synthesized by ruminal microorganisms (bacteria and fungi) and are added to feed to increase fiber degradation (Campioni et al., 2020); due to the high fiber content of fibrous feeds, ruminal enzymes sometimes cannot access the plant cell wall, and feed digestibility is reduced (Togtokhbayar et al., 2015). The use of EFEs could increase cellulose and hemicellulose degradation.

Cellulases are inducible enzymes synthesized by a wide range of microorganisms, including fungi and bacteria (Sang-Mok \& Koo, 2001; Campioni et al., 2020). Microorganisms can be aerobic, anaerobic, mesophilic or thermophilic; among them, the genera Clostridium, Cellulomonas, Thermomonospora, Trichoderma and Aspergillus are the most widely studied cellulase producers (Sun \& Cheng, 2002; Dhillon et al., 2011), of which the species $A$. niger is recognized as a cellulase producer (Onsori et al., 2005). Microbial cellulases have received attention as biocatalysts due to their complex nature and wide applications (Henrissat et al., 1998); for example, in animal feed, their addition to the diet of ruminants improves fiber digestion (Alsersy et al., 2015; Salem et al., 2015a, 2015b).

Xylanases, which are responsible for hemicellulose hydrolysis, include endoxylanases, which generate xylose oligomers, and $\beta-1-4$ xylosidases, which hydrolyze xylases. The most important enzymes involved in the degradation of hemicellulose are xylanases (E.C.3.2.1.8) and $\beta-1-4$ xylanases (E.C.3.2.1.37) (Bhat \& Hazlewod, 2003). Xylan is the main component of hemicellulose, and by the action of a complex enzymatic system, it is hydrolyzed and converted into its constituent sugars (Breccia et al., 1998).

Currently, little attention has been paid to the use of "maguey pulquero" (Agave salmiana, A. mapisaga, and A. atrovirens), which has been reported from 136 of the 150 species of Agave in Mexico (Novel, 1998). These species are used in food, fiber, fodder, medicine, construction, and production of alcoholic beverages. Maguey extract is used for the preparation of "pulque" whose product of fermentation is a sweet, colorless, transparent liquid with a light herbal scent that is rich in carbohydrates and protein. This extract contains organic forms of nitrogen such as amino acids; while little attention has been paid to the organic forms of protein in maguey extract, all of the proteinogenic amino acids found in the phloem supplemented with the high content of sugars directly influence the fermentation process of the preserved organic materials, making the use of this extract interesting and necessary in order to analyze its effect, in comparison with those of other additives already tested, in improving the degradation of raw fiber and possible protein enrichment in forage feed for cattle.

Feed additives, such as exogenous enzymes (i.e., xylanases, cellulases, mannases), have been used to improve the degradation of carbohydrates and cell walls in ruminant animals (Vallejo et al., 2016; Salem et al., 2015a), but little is known about the use of maguey extract as a natural feed additive. Since the additives (i.e., maguey extract, Aguamiel, Salem et al., 2017) used have common amino acids, sugars, and other elements, the aim of this study was to compare the effects of xylanase and cellulose enzymes (synthetic origin) with those of maguey extract (natural organic compound) in terms of chemical composition, in vitro gas production and fermentation parameters when all are applied to four maize silage varieties. 


\section{Materials and methods}

\section{Material evaluated}

Four genotypes of corn forage (Zea mays) were used: two Creole native breeds, Cacahuacintle (white grain) and San Diego (yellow grain) (the first one, a breed of Cacahuacintle, is a floury corn, with large and soft seeds that predominates in the high mountains of the State of Mexico; and the second one belongs to the breed Conico, has jagged grains and originated in the High Valleys of the transverse volcanic axis of Mexico. It was obtained from the cross between the breed Palomero Toluqueño with the genotype Cacahuacintle) and two hybrids, P-1832 (yellow grain) and Victoria (white grain), whose production characteristics are described by Franco et al. (2015). Cutting of the plants took place when the grains of corn reached a doughy state, at 155, 149, 176 and 168 days after planting for the four genotypes, respectively. Whole plants of the experimental plots of each variety were cut and then chopped in a Wiley mill (DPM Junior, Noriega) to obtain a particle size of 1.5 to $4.0 \mathrm{~cm}$; subsequently, to form microsilos, $1 \mathrm{ml}$ of enzyme (xylanase and cellulase) or maguey extract was used per $\mathrm{kg}$ of silage fresh matter per variety in triplicate. The xylanase (XYL) product consisted of 34.000 to 41.000 units xylanase $\mathrm{g}^{-1}$, of 12,000 to 15,000 units of $\beta$-glucanase $\mathrm{g}^{-1}$ and 45,000 to 55,000 units of cellulose $\mathrm{g}^{-1}$, cellulase (CELL) consisted of 30.000 to 36.000 units cellulose $\mathrm{g}^{-1}$ and from 7.500 to 10.000 units $\beta$-glucanase $\mathrm{g}^{-1}$ and the maguey extract (maguey extract) consisted of $8.62 \%$ sugars (fructose, dextrose, sucrose), $3 \%$ crude protein, $0.3 \%$ amino acids and 3\% ash; the respective control groups received no additives. Subsequently, three cylinders were filled with $15 \times 30 \mathrm{~cm}$ polyvinyl chloride with each of the varieties of maize and their respective treatments, leaving the respective controls without substrate, and each fodder cylinder was compacted, sealed with metal and finally covered with black plastic. The microsilos were stacked in a cool area and covered for six months at room temperature (Bartosik, 2012).

\section{Chemical composition}

Forage samples for post conservation chemical analysis were collected from silages (4 silages per sample) at opening. A minimum of 6 cores were taken from each micro silo and pooled to produce one sample per bag. Samples for chemical analysis were frozen at $-18{ }^{\circ} \mathrm{C}$ before chemical composition analysis.

Pooled samples of feeds were ground to a $1 \mathrm{~mm}$ maximum size with a Wiley Mini Cutting Mill model 5KH39QN5525 and analyzed in duplicate following the procedures of AOAC (1997). The $\mathrm{pH}$ was measured immediately after opening the silages; dry matter (DM) was determined by oven drying at $105{ }^{\circ} \mathrm{C}$ to constant weight (ref. 934.01), organic matter and total ash by muffle furnace (ref. 942.05), and crude protein (CP) by the Kjeldahl method (ref. 976.05). The contents of neutral detergent fiber (NDF), acid detergent fiber (ADF) and lignin (ADL) were determined according to Van Soest et al. (1991) using an Ankom 200 fiber analyzer (Ankom Technol. Co. Macedon, NY. USA). NDF was assayed without $\alpha$-amylase. Both NDF and ADF are expressed without residual ash. The moisture content of the silages was determined through distillation with toluene (Haigh \& Hopkins, 1977).

\section{In vitro gas production}

The corn silages previously inoculated with XIL, CEL and maguey extract were treated with the ruminal solution, collected during the first day of incubation from two dry Holstein cows $(450 \mathrm{~kg}$ LW) fed with a diet based on corn silage/alfalfa hay (60/40 ratio) supplemented with commercial concentrate (Purina R), and water was given ad libitum. The ruminal fluid was extracted at 08:00 a.m. before the cows were fed, transported in a thermos to the laboratory, filtered using a triple layer of cheesecloth, then kept at a temperature of $39^{\circ} \mathrm{C}$ and gassed with $\mathrm{CO}_{2}$. Stirring solutions (Menke \& Steingas, 1988) were maintained at 39 
${ }^{\circ} \mathrm{C}$, and $10 \%$ ruminal fluid was added and mixed with buffer solution. A total of $800 \mathrm{mg}$ of DM from each of the treatments was weighed and placed into 48 120-ml amber bottles (considering the 16 treatments in triplicate), and $90 \mathrm{ml}$ of buffer solution was added. Finally, $101 \mathrm{ml}$ of ruminal-buffer mixture solution was mixed with a 9:1 buffer/ ruminal fluid ratio. After agitation, flasks were placed in a water bath at $39^{\circ} \mathrm{C}$. Subsequently, the pressure (PSI) was determined using a pressure transducer (DELTA OHM HD2124.1), and gas production was measured at $0,3,6,9,12,24,36$, 48, 72 and 96 h of incubation. For gas correction, four flasks were used without substrate as blanks; moreover, four bottles with barley hay were used as standards (Theodorou et al., 1994).

The kinetic parameters of gas production (GP) were estimated through an iterative procedure of nonlinear regression analysis (PROC NLIN, SAS Institute 2002) according to Krishnamoorthy et al. (1991), calculated as:

$\mathrm{GP}=\mathrm{b}\left(1-\mathrm{e}-^{\mathrm{c}(\mathrm{t}-\mathrm{l})}\right)$

where GP is the volume of GP at time ( $\mathrm{t})$; $\mathrm{b}$ is the asymptotic GP ( $\left.\mathrm{ml} \mathrm{g}^{-1} \mathrm{DM}\right)$; $\mathrm{c}$ is the rate of GP $\left(\mathrm{g} \mathrm{h}^{-1}\right)$, and $l(\mathrm{~h})$ is the discrete lag time prior to gas production.

\section{Ruminal fermentation in vitro}

After the incubation period, the accumulated gas was released, and the DM residues of the fermentation were filtered using a 72-micron pore size deposited on crucibles. Then, the samples were dried using a stove at $110^{\circ} \mathrm{C}$ for 24 hours. When the weight was calculated, the dry matter disappearance (DMD) was determined; then, samples were placed inside a muffle at $600{ }^{\circ} \mathrm{C}$ for 4 hours and weighed, and the $\mathrm{OM}$ disappearance (OMD) was determined.

At the end of the incubation, DM degradability (DMD, mg) and OM degradability (OMD, mg) were determined; gas yield ( $\left.\mathrm{GY}_{24 \mathrm{~h}}\right)$ was calculated as the volume of gas ( $\mathrm{ml}$ gas g-1 $\mathrm{DM})$ produced after $24 \mathrm{~h}$ of incubation divided by the amount of DMD (g) as:

Gas yield $\left(\mathrm{GY}_{24 \mathrm{~h}}\right)=\mathrm{ml}$ gas. $\mathrm{g} \mathrm{DM}_{24 \mathrm{~h}} \mathrm{~g}^{-1} \mathrm{DMD}$

Metabolizable energy (ME, MJ kg-1 DM) was estimated according to Menke et al. (1979), Theodorou et al. (1994) and Robles Jimenez et al. (2019) as:

$\mathrm{ME}=2.20+0.136 \mathrm{GP}\left(\mathrm{ml} 0.5 \mathrm{~g}^{-1} \mathrm{DM}\right)+0.057$
$\mathrm{CP}\left(\mathrm{g} \mathrm{kg}^{-1} \mathrm{DM}\right)$

Relative gas production (RGP) was calculated as milliliters of gas per gram of DMD after

$48 \mathrm{~h}$ incubation $\left(\mathrm{DMD}_{48 \mathrm{~h}}\right.$.

Short chain fatty acid concentrations (SCFAs) were calculated according to Getachew et al. (2002) as

where GP is the $24 \mathrm{~h}$ net gas production $(\mathrm{ml} 200$ $\left.\mathrm{mg}^{-1} \mathrm{DM}\right)$.

Microbial CP biomass production was calculated according to Blümmel et al. (1997) as:

where $2.2 \mathrm{mg} \mathrm{ml}^{-1}$ is a stoichiometric factor that expresses the $\mathrm{mg}$ of $\mathrm{C}, \mathrm{H}$ and $\mathrm{O}$ required for the production of SCFA gas associated with the production of $1 \mathrm{ml}$ of gas.

\section{Statistical analysis}

Data were analyzed as a completely randomized design with a $4 \times 4$ factorial arrangement (Steel et al., 1997), where the treatments were maize varieties $(\mathrm{V})(\mathrm{n}=4)$ and additives (Control, XYL, CELL and maguey extract) $(A)(n=4)$, with three replications. Data were subjected to analysis of variance (ANOVA) using the general linear model procedure (GLM; SAS, 2002). The univariate 
procedure of SAS was used to test for a normal distribution of the data.

The statistical model was as follows:

$\mathrm{Yijk}=\mu+\mathrm{V}_{\mathrm{i}}+\mathrm{A}_{\mathrm{j}}+(\mathrm{V} * \mathrm{~A})_{\mathrm{ij}}+\mathrm{E}_{\mathrm{ijk}}$

where $Y_{\mathrm{ijk}}=$ response variable of silages treated with xylanase, cellulase and maguey extract; $\mu=$ general mean; $\mathrm{V}_{\mathrm{i}}=$ effect of the ith maize variety $(i=1-4) ; J=$ effect of the $j^{\text {th }}$ additive $(j=1-4) ;(V$ $* A)_{i j}=$ effect of the interaction between the $i^{\text {th }}$ variety and the $\mathrm{j}^{\text {th }}$ additive; $\mathrm{E}_{\mathrm{ijk}}=$ experimental error of the $\mathrm{i}^{\text {th }}$ variety and the $\mathrm{j}^{\text {th }}$ and $\mathrm{k}^{\text {th }}$ additive repetitions. Differences among means were tested using Tukey's HSD (Snedecor and Cochran 1994), with significance declared if $\mathrm{P}<0.05$.

\section{Results}

\section{Chemical composition}

The maize varieties showed a significant effect $(\mathrm{P}<0.05)$ on DM, CP, NDF and ADF, and the additives had a significant effect $(\mathrm{P}<0.05)$ on $\mathrm{DM}$, $\mathrm{OM}, \mathrm{CP}$ and $\mathrm{ADF}$. The $\mathrm{CP}$ contents of corn silages from San Diego and Cacahuacintle were lower
$(\mathrm{P}<0.05)$ than those of silages from the $\mathrm{P}-1832$ and Victoria hybrids. The concentrations of NDF and ADF were higher $(\mathrm{P}<0.05)$ for the hybrids, especially for Victoria, compared with the native corns. The inclusion of maguey extract, CEL and $X Y L$ enzymes increased $(\mathrm{P}<0.05)$ the $\mathrm{CP}$ content compared to those of the control groups. The addition of maguey extract decreased $(\mathrm{P}<0.05)$ the content of ADF compared with the rest of the treatments (Table 1).

\section{In vitro gas production}

The application of enzymes and maguey extract increased the GP ( $\left.\mathrm{ml} \mathrm{gas} \mathrm{g}^{-1} \mathrm{DM}\right)$ of the four genotypes, with higher $(\mathrm{P}<0.05)$ GP observed for Cacahuacintle and San Diego (227 $2 \mathrm{ml}$ gas $\mathrm{g}^{-1} \mathrm{DM}$ ) and the lowest for Victoria (198 $\mathrm{ml}$ gas $\mathrm{g}^{-1} \mathrm{DM}$ ); however, the greatest accumulation of gas was at 24 hours, and the fermentation rate "b" was higher $(\mathrm{P}<0.05)$ for San Diego and Cacahuacintle $(0.0390 \pm 8)$ than for the corn hybrids $(0.0308 \pm 4)$ (Figure 1, Table 2). The use of XYL increased gas production (229 $\left.\mathrm{ml} \mathrm{gas} \mathrm{g}^{-1} \mathrm{DM}\right)$ $(\mathrm{P}<0.05)$, followed by CEL and maguey extract $\left(220 \pm 1 \mathrm{ml} \mathrm{gas} \mathrm{g}^{-1} \mathrm{DM}\right)$ (Figure 2). The addition of maguey extract, CEL and XYL resulted in a

Table 1. Chemical composition ( $\mathrm{g} \mathrm{kg} / \mathrm{DM})$ of silage from four corn varieties $(\mathrm{V})$ treated with maguey extract, cellulose and xylanase

\begin{tabular}{|c|c|c|c|c|c|c|c|c|c|c|c|c|}
\hline \multirow[b]{2}{*}{ Item } & \multicolumn{4}{|c|}{ Variety (V) } & \multicolumn{4}{|c|}{ Treatment (Tx) } & \multirow{2}{*}{$\begin{array}{c}\text { SEM } \\
\mathrm{V}\end{array}$} & \multicolumn{3}{|c|}{ P value } \\
\hline & San Diego & Cacahuacintle & P-1832 & Victoria & Control & $\begin{array}{l}\text { Maguey } \\
\text { extract }^{\dagger}\end{array}$ & Cellulose & Xylanase ${ }^{\S}$ & & Tx & VxTx & \\
\hline $\mathrm{DM}$ & $229 a$ & $210 \mathrm{a}$ & $203 a$ & $171 \mathrm{~b}$ & $180 \mathrm{~b}$ & $204 a b$ & $216 \mathrm{a}$ & $213 a$ & 7.01 & 0.001 & 0.004 & 0.288 \\
\hline $\mathrm{OM}$ & 920 & 913 & 921 & 913 & $903 c$ & $924 a b$ & $927 \mathrm{a}$ & $913 b c$ & 3.18 & 0.143 & 0.001 & 0.001 \\
\hline $\mathrm{CP}$ & $76 \mathrm{bc}$ & $71 \mathrm{c}$ & $80 \mathrm{ab}$ & $83 a$ & $72 b$ & $82 \mathrm{a}$ & $77 \mathrm{a}$ & $78 \mathrm{a}$ & 1.30 & 0.001 & 0.001 & 0.001 \\
\hline $\mathrm{NDF}$ & $487 \mathrm{~b}$ & $495 \mathrm{ab}$ & $548 \mathrm{a}$ & $544 \mathrm{a}$ & 546 & 514 & 489 & 525 & 15.23 & 0.010 & 0.080 & 0.308 \\
\hline $\mathrm{ADF}$ & $207 \mathrm{~b}$ & $180 \mathrm{~b}$ & $203 b$ & $245 \mathrm{a}$ & $206 a b$ & $190 \mathrm{~b}$ & $205 \mathrm{~b}$ & $234 a$ & 9.22 & 0.002 & 0.017 & 0.031 \\
\hline
\end{tabular}

${ }^{\dagger}$ Maguey extract had $8.62 \%$ sugars (fructose, dextrose, sucrose), $3 \%$ protein, $0.3 \%$ amino acids and $3 \%$ ash.

${ }^{\ddagger}$ Cellulose had 30000 to 36000 units of cellulose per $\mathrm{g}^{-1}$ and 7500 to 10000 units of $\beta$-gluconase per $\mathrm{g}^{-1}$.

${ }^{\S}$ Xylanase contained 34000 to 41000 units of xylanase g-1, 12000 to 15000 units of $\beta$-gluconase $\mathrm{g}^{-1}$ and 45000 to 55000 units of cellulose $\mathrm{g}^{-1}$.

$\mathrm{DM}$, dry mater; OM, organic matter; $\mathrm{CP}$, crude protein; NDF, neutral detergent fiber; $\mathrm{ADF}$, acid detergent fiber.

SEM, standard error of the mean. Different letters in the same row indicate significant differences $(\mathrm{P}<0.05)$. 
linear increase in GP (gas $\mathrm{ml}^{\text {hour }}{ }^{-1}$ ) over time, with a greater accumulation of gas than in the control silage (Table 2).

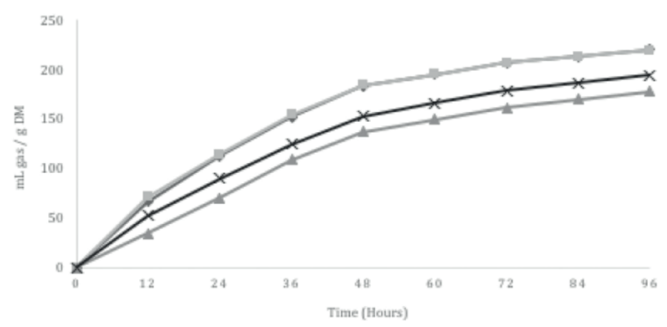

Figure 1. Cumulative gas production profiles $\left(\mathrm{ml}\right.$ gas $^{-1}$ $\mathrm{DM})$ from in vitro fermentation of silage from four corn forages (native San Diego -m-, and Cacahuacintle - $\$$-maize forage genotypes, and hybrids P-1832 -x- and Victoria- $\mathbf{A}-)$ with different exogenous enzyme preparations (ENZ, $\mathrm{g} \mathrm{g}^{-1}$ DM) in cows. S.E.M. is for the overall fit, and $\mathrm{P}^{\prime}$ is for the effect of extract dose.

\section{Ruminal fermentation in vitro}

The ruminal $\mathrm{pH}$ was lowest $(\mathrm{P}<0.05)$ for the San Diego variety (4.31); likewise, maguey extract (4.87) decreased the $\mathrm{pH}$ of the silage $(\mathrm{P}<0.05)$, followed by XYL (4.70) and CEL (5.03). The addition of enzymes or maguey extract increased the concentration of ME $(12.4 \pm 0.2 \mathrm{MJ} \mathrm{ME})$ and OMD $\left(745 \pm 10 \mathrm{mg} \mathrm{g}^{-1}\right)$ compared with the control treatment (10.1 Mj ME, $659 \mathrm{mg} \mathrm{g}^{-1}$, respectively), while the concentrations of SCFAs and MCP were higher $(\mathrm{P}<0.05)$ for the CEL and XYL groups than for the control. $\mathrm{GY}_{24 \mathrm{~h}}$ was lower $(\mathrm{P}<0.05)$

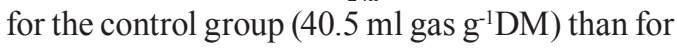
the rest of the treatment groups (Table 2), with a higher XYL (74.9 $\left.\mathrm{ml} \mathrm{gas} \mathrm{g}^{-1} \mathrm{DM}\right)$.

Table 2. Gas production ( $\mathrm{ml}$ gas $\left.\mathrm{g}^{-1} \mathrm{DM}\right)$ and ruminal in vitro fermentation parameters for silage from different corn varieties (V) treated with maguey extract, cellulose and xylanase (Tx).

\begin{tabular}{|c|c|c|c|c|c|c|c|c|c|c|c|c|}
\hline \multirow[b]{2}{*}{ Item } & \multicolumn{4}{|c|}{ Variety (V) } & \multicolumn{4}{|c|}{ Treatment (Tx) } & \multicolumn{4}{|c|}{$\mathrm{P}$ value } \\
\hline & $\begin{array}{c}\text { Cacahua } \\
\text { cintle }\end{array}$ & $\begin{array}{c}\text { San } \\
\text { Diego }\end{array}$ & P-1832 & Victoria & Control & $\begin{array}{l}\text { Maguey } \\
\text { extract }^{\dagger}\end{array}$ & Cellulose & Xylanase $^{\S}$ & SEM & $\mathrm{V}$ & $\mathrm{Tx}$ & VxTx \\
\hline $\mathrm{A}$ & $229.0 \mathrm{a}$ & $226.2 \mathrm{a}$ & $209.8 b$ & $198.3 \mathrm{c}$ & $192.5 \mathrm{c}$ & $220.3 b$ & $221.4 b$ & $229.2 \mathrm{a}$ & 2.021 & 0.001 & 0.001 & 0.001 \\
\hline b & $0.0380 \mathrm{a}$ & $0.0396 \mathrm{a}$ & $0.0304 \mathrm{~b}$ & $0.0313 \mathrm{~b}$ & $0.0306 \mathrm{~b}$ & $0.0371 \mathrm{a}$ & $0.0362 \mathrm{a}$ & 0.0353 & 0.000 & 0.001 & 0.001 & 0.001 \\
\hline $\mathrm{c}$ & $-0.0436 a$ & $-0.0407 a$ & $-0.0336 a$ & $-0.0589 b$ & $-0.0575 b$ & $-0.0522 b$ & $-0.0377 \mathrm{a}$ & $-0.0294 a$ & 0.002 & 0.001 & 0.001 & 0.001 \\
\hline $\begin{array}{l}\text { Lag } \\
\text { time }\end{array}$ & $1.29 b$ & $1.27 \mathrm{~b}$ & $0.96 \mathrm{c}$ & $2.85 \mathrm{a}$ & $2.25 \mathrm{a}$ & $1.87 \mathrm{~b}$ & $1.20 \mathrm{c}$ & $1.05 \mathrm{c}$ & 0.066 & 0.001 & 0.001 & 0.001 \\
\hline Gas3 & $8.01 \mathrm{a}$ & $6.74 \mathrm{a}$ & $7.55 \mathrm{a}$ & $2.50 \mathrm{~b}$ & $3.84 \mathrm{c}$ & $5.97 \mathrm{~b}$ & $7.36 \mathrm{ab}$ & $7.62 \mathrm{a}$ & 0.367 & 0.001 & 0.001 & 0.002 \\
\hline Gas6 & $24.35 \mathrm{a}$ & $24.45 \mathrm{a}$ & $20.90 b$ & $10.12 \mathrm{c}$ & $11.91 \mathrm{~d}$ & $19.66 \mathrm{c}$ & $22.71 b$ & $25.54 \mathrm{a}$ & 0.533 & 0.001 & 0.001 & 0.001 \\
\hline Gas9 & $45.44 b$ & $48.75 \mathrm{a}$ & $36.63 c$ & $24.48 \mathrm{~d}$ & $23.63 \mathrm{~d}$ & $38.69 \mathrm{c}$ & $43.64 b$ & $49.35 \mathrm{a}$ & 0.678 & 0.001 & 0.001 & 0.001 \\
\hline Gas 12 & $66.43 b$ & $71.21 \mathrm{a}$ & $52.72 \mathrm{c}$ & $34.72 \mathrm{~d}$ & $35.47 \mathrm{~d}$ & $57.03 c$ & $62.87 b$ & $69.71 \mathrm{a}$ & 0.886 & 0.001 & 0.001 & 0.001 \\
\hline Gas24 & $112.88 \mathrm{a}$ & $114.10 \mathrm{a}$ & $90.13 b$ & $70.48 \mathrm{c}$ & $69.81 \mathrm{c}$ & $100.63 b$ & $106.30 \mathrm{a}$ & $110.85 \mathrm{a}$ & 1.433 & 0.001 & 0.001 & 0.001 \\
\hline Gas36 & $151.96 \mathrm{a}$ & $154.25 \mathrm{a}$ & $124.84 b$ & $108.72 \mathrm{c}$ & $104.75 \mathrm{c}$ & $141.15 b$ & $144.35 \mathrm{ab}$ & $149.54 \mathrm{a}$ & 1.659 & 0.001 & 0.001 & 0.001 \\
\hline Gas48 & $183.52 \mathrm{a}$ & $183.65 \mathrm{a}$ & $152.79 b$ & $137.26 \mathrm{c}$ & $131.78 \mathrm{c}$ & $172.28 \mathrm{~b}$ & $173.34 \mathrm{ab}$ & $179.82 \mathrm{a}$ & 1.763 & 0.001 & 0.001 & 0.001 \\
\hline Gas 72 & $206.34 \mathrm{a}$ & $206.28 \mathrm{a}$ & $178.57 \mathrm{~b}$ & $161.59 \mathrm{c}$ & $155.50 \mathrm{c}$ & $196.25 b$ & $197.29 \mathrm{ab}$ & $203.75 a$ & 1.811 & 0.001 & 0.001 & 0.001 \\
\hline Gas96 & $220.20 \mathrm{a}$ & $219.45 a$ & $194.41 b$ & $177.77 \mathrm{c}$ & $170.90 \mathrm{c}$ & $209.22 b$ & $211.97 \mathrm{ab}$ & $219.74 a$ & 2.037 & 0.001 & 0.001 & 0.001 \\
\hline $\mathrm{pH}$ & $5.09 \mathrm{~b}$ & $4.31 \mathrm{c}$ & $4.95 b$ & $6.37 \mathrm{a}$ & $6.13 \mathrm{a}$ & $4.87 b$ & $5.03 \mathrm{~b}$ & $4.70 b$ & 0.225 & 0.001 & 0.001 & 0.001 \\
\hline DMD & $649.8 b$ & $676.5 \mathrm{a}$ & $617.2 \mathrm{c}$ & $553.4 d$ & $551.2 \mathrm{c}$ & $613.5 b$ & $663.4 \mathrm{a}$ & $668.9 \mathrm{a}$ & 5.344 & 0.001 & 0.001 & 0.001 \\
\hline OMD & $726.5 \mathrm{ab}$ & $744.3 \mathrm{a}$ & $718.6 \mathrm{~b}$ & $705.3 b$ & $659.5 b$ & $746.3 \mathrm{a}$ & $734.5 \mathrm{a}$ & $754.4 \mathrm{a}$ & 6.630 & 0.002 & 0.001 & 0.001 \\
\hline ME & $12.4 \mathrm{a}$ & $12.7 \mathrm{a}$ & $11.6 \mathrm{~b}$ & $10.7 \mathrm{c}$ & $10.1 \mathrm{~b}$ & $12.3 \mathrm{a}$ & $12.4 \mathrm{a}$ & $12.7 \mathrm{a}$ & 0.109 & 0.001 & 0.001 & 0.001 \\
\hline SCFA & $0.496 a$ & $0.502 \mathrm{a}$ & $0.395 b$ & $0.308 \mathrm{c}$ & $0.305 \mathrm{c}$ & $0.442 b$ & $0.467 \mathrm{a}$ & $0.488 \mathrm{a}$ & 0.006 & 0.001 & 0.001 & 0.001 \\
\hline MCP & $165.4 b c$ & $193.7 \mathrm{a}$ & $189.5 \mathrm{ab}$ & $162.3 \mathrm{c}$ & $175.2 \mathrm{ab}$ & $153.2 \mathrm{~b}$ & 197.1a & $185.5 \mathrm{a}$ & 6.584 & 0.002 & 0.004 & 0.001 \\
\hline $\mathrm{GY}_{24 \mathrm{~h}}$ & $74.1 \mathrm{a}$ & $77.3 \mathrm{a}$ & $56.5 b$ & $40.7 \mathrm{c}$ & $40.5 \mathrm{~d}$ & $62.5 \mathrm{c}$ & $70.8 \mathrm{~b}$ & $74.9 \mathrm{a}$ & 1.045 & 0.001 & 0.001 & 0.001 \\
\hline
\end{tabular}

${ }^{\dagger}$ Maguey extract had 8.62\% sugars (fructose, dextrose, sucrose), 3\% protein, $0.3 \%$ amino acids and 3\% ashes.

${ }^{\ddagger}$ Cellulose had 30000 to 36000 units of cellulose per $\mathrm{g}^{-1}$ and 7500 to 10000 units of $\beta$-gluconase per $\mathrm{g}^{-1}$.

${ }^{\S}$ Xylanase contained 34000 to 41000 units of xylanase $\mathrm{g}^{-1}, 12000$ to 15000 units of $\beta$-gluconase $\mathrm{g}^{-1}$ and 45000 to 55000 units of cellulose. $\mathrm{g}^{-1}$.

a: gas production $\left(\mathrm{ml} \mathrm{g}^{-1} \mathrm{MS}\right)$; b: fermentation rate $\left(\mathrm{h}^{-1}\right)$; c, fermentation rate $\left(\mathrm{h}^{-1 / 2}\right)$; lag time: $\left(\mathrm{h}^{-1}\right)$. DMD: Dry mater digestibility ( $\left.\mathrm{mg} \mathrm{g}^{-1} \mathrm{DM}\right)$; OMD: OM digestibility ( $\left.\mathrm{mg} \mathrm{g}^{-1} \mathrm{DM}\right)$; ME, Metabolizable energy ( $\left.\mathrm{Mj} \mathrm{kg}^{-1} \mathrm{DM}\right)$; SCFA: Short chain fatty acids (mmol $\left.\mathrm{g}^{-1} \mathrm{DM}\right)$; MCP: Microbial crude protein $\left(\mathrm{mg} \mathrm{g}^{-1} \mathrm{DM}\right) ; \mathrm{GY}_{24 \mathrm{~h}}$ Gas yield at $24 \mathrm{~h}\left(\mathrm{ml} \mathrm{gas} \mathrm{g}^{-1} \mathrm{DM}\right)$.

SEM: standard error of the mean.

${ }^{a b c}$ Different letters in the same row indicate significant differences $(\mathrm{P}<0.05)$. 


\section{Discussion}

\section{Chemical composition}

The enzymes and maguey extract showed a greater contribution to dry matter in the native corns San Diego and Cacahuacintle than in the P-1832 and Victoria hybrids. This was attributable to the addition of exogenous fibrolytic enzymes, which altered the structure of the fiber and stimulated microbial colonization due to the strong relationship of the enzymes with the substrate when incorporated into the corns (Settimi et al., 2013). In the present study, the DM content was higher for CELL, XYL and ME than for the control treatment groups because the addition of exogenous fibrolytic enzymes (EFE) such as cellulase or xylanase increases the degradation and fermentation of maize fodder (Valdes et al., 2015; Vallejo et al., 2016). Kuhad et al. (2011) observed that the activity of cellulases can cause partial hydrolysis of the plant cell wall during ensiling; in addition to adding EM, which included 8.6\% sugars, those spiked enzymes were actively involved in the fermentation of carbohydrates released by the feed enzymes and protein degradation to amino acids, stabilizing the silage. The highest content of $\mathrm{CP}$ was realized with the inclusion EM, which could have been due to the effect caused by the supply of $0.3 \%$ amino acids and $3 \%$ protein. The effect of adding enzymes rich in serine and threonine and composed of approximately 35 amino acids independent of the cellulase domain resulted in increases in the $\mathrm{CP}$ content of the silage when EM was added.

Corn stover can be used in feed for ruminants to improve its nutritional value (Elghandour et al., 2014) via the exogenous fibrolytic enzymes that enhance the degradation of carbohydrates and cell walls in the phase of ruminal preincubation, which is consistent with the decrease in NDF when applying CELL, XYL and maguey extract in the present study; the activity of these products, mainly in native corns (i.e., corn stover). Cacahuacintle was also evident, as indicated by a trend $(\mathrm{P}=0.08)$ in NDF content. Muttoni et al. (2013) found that the range of variability of NDF in local maize varieties was 46.8 to $72 \%$ and $42-78 \%$ in lines derived from different germplasms, ranking in lower concentrations in maize cultivars evaluated in this study. Nsereko et al. (2000) added fibrolytic enzymes to fodder before ingestion and altered the structure of the food, making the fodder more susceptible to ruminal hydrolysis. Moreover, Casler (2001) found a reduction in the NDF content and an increase in the proportion of highly digestible soluble components with the addition of enzymes. The inclusion of enzymes, such as CELL, showed the greatest effect with the least content of NDF and ADF in relation to the control treatment, which was in accordance with the improved fiber digestion noted by Al Sersy et al. (2015) following the addition of cellulolytic enzymes to the diet of ruminants. Settimi et al. (2013) indicate that fibrolytic enzymes improve the initial degradation of structural carbohydrates of plants. The lowest content of ADF was found using maguey extract, which could be due to the high amount of sugars in this additive, which optimized the fermentation of the corn silage. According to Forsberg et al. (2000), polysaccharides provide fermentable carbohydrates to stimulate microbial growth.

\section{In vitro gas production}

The activity of the XYL, CELL and maguey extracts was reflected more in the Cacahuacintle and San Diego native corns with respect to that in the P-1832 and Victoria hybrids, given their remarkable increase in GP, the time of fermentation rate and the delay of incubation (Table 2, Figure 1), which could be because these germplasms, which are associated with a low lignin content and high content of polyphenolic soluble materials, are adapted to the highlands and tend to accumulate anthocyanins in the midribs and stem pith. The maguey extract added sugars including glucose, fructose and sucrose, in addition to releasing polysaccharides in the corn plant, providing 
fermentable carbohydrates to stimulate microbial growth (Vallejo et al., 2016) and increasing the number of fibrolytic and non-fibrolytic bacteria in the rumen, which utilize polysaccharides (Vallejo et al., 2016).

The criteria linked to the GP were more efficient in the native corns, except in terms of the lag time for the hybrid P-1832, which showed the fastest time (0.96 h); according to Franco et al. (2015), the later plant material required 176 days to harvest for silage. Van Soest (1994) stated that genotypes with longer vegetative stages and later maturity tend to be less lignified than early maturing genotypes. XYL was the most efficient enzyme in terms of GP, fermentation time, and lag time and had the highest cumulative GP; if the enzyme affected the GP until the end of fermentation, this meant that the enzyme increased the fermentable material. The addition of XYL, CELL and maguey extract resulted in better GP and other variables than the control (Figure 2). Salem et al. (2015a) found that the efficacy of enzymes depends upon the substrate specificity and dose of the enzyme; in this study, the dose of $1 \mathrm{ml} \mathrm{kg}$ fresh matter added to corn substrate was effective according to the results obtained, with continuous activity of GP up to 96 h. However, Vallejo et al. (2016) noted that the dose of $40 \mathrm{mg} \mathrm{g}^{-1}$ of xylanase or cellulase as DM applied to corn fodder resulted in greater GP than other enzyme levels, with continuing

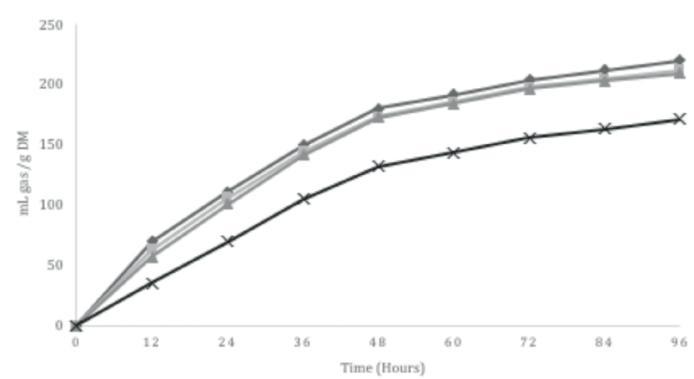

Figure 2. Cumulative gas production profiles (ml gas $\mathrm{g}^{-1}$ DM) from in vitro fermentation of four corn silages with different exogenous enzyme preparations (ENZ, $\mathrm{g} \mathrm{g}^{-1} \mathrm{DM}$ ) in cows. ( $\bullet$, Xylanase; - --, Cellulase; $-\boldsymbol{\Delta}-$-, Maguey extract; -X-, Control); S.E.M. is for the overall fit, and $\mathrm{P}$ ' is for the effect of the extract dose. effects up to $72 \mathrm{~h}$. Moreover, it was noted that the application of two cellulases from Aspergillus niger and Trichoderma longibrachiatum at doses of $30 \mathrm{U} \mathrm{g}^{-1}$ substrate ( $70 \%$ grass hay and $30 \%$ concentrate) showed greater disappearance of DM after 6 and $24 \mathrm{~h}$ without effects after 48 $\mathrm{h}$ of incubation.

\section{Ruminal fermentation in vitro}

The corn silages from San Diego, P-1832 and Cacahuacintle showed decreased $\mathrm{pH}$, as did that treated with XYL, maguey extract and CELL, compared with that of the control, which could be due to the aggressive fermentation of fresh forage with the addition of sugars of maguey extract and the direct application of exogenous enzymes that favor the formation of a stable substrate, which increases the effectiveness of these enzymes in the rumen (Settimi et al., 2013). This was clearly the situation in the present study since the greatest effect on the DMD and OMD was observed for the varieties and additives mentioned. In contrast, the hybrid Victoria had the highest $\mathrm{pH}$, with lower activity of ruminal fermentation for DMD, OMD, ME, SCFA, MCP, and $\mathrm{GY}_{24 \mathrm{~h}}$, similar to the control treatment, which could be due to the difficulty of fermentation of these plants given the thickness of their stems. According to Franco et al. (2015), the Victoria cultivar has a thick stem with a diameter of $2.28 \mathrm{~cm}$; moreover, ChalquerScott and Fuchigami (1989) demonstrated that low temperature stress can cause cell wall thickening as a physiological response to increased resistance of plants. Boon et al. (2008) noted that the stem has the worst digestibility of all maize plant parts, since it is relatively more lignified, and according to Barrière et al. (2005), the lignin is the indigestible component of the fiber fraction, playing an important part in strength but decreasing digestibility of the stem cell wall.

The XYL, CELL and maguey extract objectively increased the DMD, OMD, ME, SCFA and MCP during in vitro fermentation of corn silage, while 
the latter was increased only with XYL and CEL compared with the control treatment; these levels were higher than the results of DMD, OMD and ME reported by Vallejo et al. (2016) when working with the addition of CELL and XYL at different doses in corn stover. In this sense, Settimi et al. (2013), working with an enzyme complex (cellulase, xylanase and $\beta$-glucosidase) applied at different doses, determined that enzymes increased the in vitro DM digestibility of corn stover but did not affect digestion after long periods of ruminal incubation; moreover, Casler (2001) found that NDF reduction translates into greater DMD, coinciding with the results of the present study.

Similar increases in OMD, ME and SCFA with the implementation of the three additives were obtained in this study; Elghandour et al. (2014) found that increased OMD-related enzymes are correlated with fermented OM; for the case of ME, Zsubori et al. (2013) reported that their close correlation is due to the OM content and the degradability of the forage cell wall, agreeing with Elghandour et al. (2014), who suggested that increases in these variables were due to supplementation of XYL and CEL in fibrous foods.

The genotypes of yellow grain (San Diego and P-1832) and the treatments XYL and CELL showed the highest MCP, which could be because the grains of yellow corn are sweeter than those of white corn, leading to accelerated fermentation of the former in addition to increases in OMD compared with that of the addition of XYL and CELL. Addition of these enzymes overcame the problem of a slow rate of digestion of low-quality forage due to long retention times in the rumen, so that exogenous fibrolytic enzymes supplemented the enzyme activities of microorganisms in the rumen and allowed better digestion of the substrate during the preliminary stages, which are the most critical for digestion (Settimi et al., 2013). The increased production of MCP with the addition of XYL and CELL was evident in the present study. Furthermore, Kung et al. (2000) found that the addition of enzymes to the feed can create a stable enzyme-food complex that protects the enzymes from ruminal proteolysis.

The highest $\mathrm{GY}_{24 \mathrm{~h}}$ was observed for the native corns San Diego and Cacahuacintle and for the enzymes XYL and CELL, followed by maguey extract, which could be due to increased fiber digestion and altered ruminal fermentation and the contribution of enzymes and sugars present in the corn silage. These results coincide with those of Vallejo et al. (2016), who added CELL and XYL at different doses, which together with the release of polysaccharides in the corn forage, caused a higher $\mathrm{GY}_{24 \mathrm{~h}}$ compared with that of the control treatment.

The main conclusions are the following. The application of xylanase, cellulase and maguey extract to maize silages increases the gas production and the rate of fermentation; similarly, in in vitro ruminal fermentation, the DMD, OMD, ME, SCFA and $\mathrm{GY}_{24 \mathrm{~h}}$ were higher in Cacahuacintle and San Diego maize than in other genotypes, and its addition increased the $\mathrm{CP}$ content of the silage with respect to that of the control treatment. The silage treated with xylanase showed the lowest $\mathrm{pH}$ and had the highest gas production at $96 \mathrm{~h}$ of incubation in comparison to that of the silage treated with cellulase and maguey extract, noting with the former treatment a greater impact on DMD and OMD. Cacahuacintle and San Diego, as native corn maize genotypes treated with xylanase, cellulase and maguey extract, showed the highest gas production and better fermentation profiles than the silage of other genotypes. maguey extract can be used as an alternative for the degradation of fiber and fermentation of corn silage. 


\title{
Resumen
}

\begin{abstract}
J.R.P. Franco Martínez, A. González Huerta, D.J. Pérez López, R. Serrato Cuevas, Salem A.Z.M., L.E. Robles-Jimenez, y M. Gonzalez-Ronquillo. 2020. Efecto de xilanasa, celulasa y extracto de maguey natural sobre la composición química producción de gas in vitro en rumen de ensilado de maíz. Int. J. Agric. Nat. Resour. El estudio consideró la aplicación de dos enzimas exógenas: xilanasa (XYL) y celulasa (CELL), y extracto de maguey (EM) (aplicando $1 \mathrm{ml}$ por $\mathrm{kg}$ de materia fresca) y Control (sin aditivo) en cuatro variedades de ensilaje de maíz (San Diego, Cacahuacintle, P -1832 y Victoria), para investigar su efecto sobre la composición química (CQ), la producción de gas (PG) y la fermentación ruminal in vitro. La PG fue medida a las $0,3,6,9,12,24,36,48,72$ y 96 horas de incubación. La materia seca desaparecida (MSD), la materia orgánica desaparecida (MOD), la energía metabolizable (EM) y los ácidos grasos de cadena corta (AGCC) se determinaron después de 96 h de incubación. Los datos se analizaron mediante un diseño completamente al azar con arreglo factorial $4 \times 4$ con tres repeticiones. La CQ mostró un efecto significativo $(\mathrm{P}<0.05)$ para las variedades, con excepción de la materia orgánica $(\mathrm{MO})$, la inclusión de aditivos incremento la materia seca (MS) y la proteína cruda $(\mathrm{PC})$. Se observó un efecto significativo $(\mathrm{P}<0.01)$ para las variedades en los parámetros de PG y la fermentación ruminal. La adición de XYL, CEL y EM promueve la degradación de la MS y aumenta la disponibilidad de energía, con una mayor producción de gas in vitro.
\end{abstract}

Palabras Clave: Aditivos, ensilado, enzimas.

\section{References}

Alsersy H, Salem A.Z.M., Borhami B.E., Olivares J., Gado H.M., Mariezcurrena M.D., Yacuot M.H., Kholif A.E., El-Adawy M., \& Hernandez S.R. 2015. Effect of Mediterranean saltbush (Atriplex halimus) ensilaging with two developed enzyme cocktails on feed intake, nutrient digestibility and ruminal fermentation in sheep. Journal of Animal Science, 86:51-58.

AOAC. 1997. Official Methods of Analysis.16th Edn. Association of Official Analytical Chemists.Arlington, VA, USA.

Barrière, Y., Alber, D., Dolstra, O., Lapierre, C., Motto, M., Ordas, A., Van Waes, J., Vlasminkel, L., Welcker, C., \& Monod, J.P. 2005. Past and prospects of forage maize breeding in Europe. I. The grass cell wall as a basis of genetic variation and future improvements in feeding value. Maydica, 50:259-274.

Beauchemin, K.A, Colombatto, D., Morgavi, D.P., Yang, W.Z., \& Rode, L.M. 2004. Mode of action of exogenous cell wall degrading enzymes for ruminants. Canadian Journal of Animal Science, 84:13-22.
Bhat, K M, \& Hazlewod, G.P. 2003. Enzymology and other characteristics of cellulases and xilanases. In: M. R. Bedford, G. G. Partridge (Eds.) Enzymes in Farm Animal Nutrition. CABI Publishing, UK. pp: 11-60.

Bartosik R. 2012. An inside look at the silo-bag system. In: Navarro S, Banks HJ, Jayas DS, Bell CH, Noyes RT, Ferizli AG, Emekci M, Isikber AA, Alagusundaram K, [Eds.] Proc 9th. Int. Conf. on Controlled Atmosphere and Fumigation in Stored Products, Antalya, Turkey. 15 - 19 October 2012, ARBER Professional Congress Services, Turkey. 117-128.

Blümmel, M., Steingss, H., \& K. Becker. 1997. The relationship between in vitro gas production, in vitro microbial biomass yield and $15 \mathrm{~N}$ incorporation and its implications for the prediction of voluntary feed intake of roughages. British Journal of Nutrition, 77:911-921.

Breccia, J., Morán, A., Castro, G., \& Siñeriz, F. 1998. Thermal stabilization by polyols of $\beta$-xylanase from Bacillus amyliquefaciens. Journal of Chemical Technology Biotechnology, 71:241-245.

Boon, E.J.M.C., Struik, P.C., Tamminga, S., Engels, F.M., \& Cone, J.W. 2008. Stem characteristics of 
two forage maize (Zea mays L) cultivars varying in whole plant digestibility. III. Intra-stem variability in anatomy, chemical composition and in vitro rumen fermentation. NJAS-Wageningen. Journal of Life Sciences, 56: 101-122.

Casler, M.D. 2001. Breeding forage crops for increased nutritional value. Advances in Agronomy, 7: 51-107

Campioni,T.S., de Azevedo Carvalho, A.F., de Figueiredo, F.C., da Silva, D.F., \& de Oliva Neto, P. 2020. Xylanases and cellulases biosynthesis by selected fungi in a simple and economic bio system using sugarcane straw. International Journal of Environmental Agricultural and Biotechnology, 5(1):217-230. doi:10.22161/ijeab.51.31

Dhillon, G.S., Oberoi, H.S., Kaur, S., Bansal, S., \& Brar, S.K. 2011. Value-addition of agricultural wastes for augmented cellulase and xylanase production through solid-state tray fermentation employing mixed-culture of fungi. Industrial Crops and Products, 34:1160-1167.

Elghandour, M.M.Y., Vazquez Ch, J.C., Salem, A.Z.M., Kholif, A.E., Martinez, C.J.S., Camacho, L.M., \& Cerrillo-Soto, M.A. 2014. Effects of Saccharomyces cerevisiae at direct addition or pre-incubation on in vitro gas production kinetics and degradability of four fibrous feeds. Italian Journal of Animal Science, 13:295-301.

Forsberg, C., Forano, E., \& Chesson, A. 2000. Microbial adherence to the plant cell wall and enzymatic hydrolysis. In: Cronje, P.B. (Ed.), Ruminant Physiology: Digestion, Metabolism, Growth and Reproduction. CABI Publishing, Wallingford, UK, pp. 79-97.

Franco, M.J.R.P., Gonzalez, H.A., Perez, L.D.J., \& Gonzalez, R.M. 2015. Phenotypic characterization of hybrids and varieties of forage maize in High Valley State of Mexico, Mexico. Rev. Mex. Ciencia Agricola, 6(8):1915-1927.

Getachew, G., Makkar, H.P.S., \& Becker, K. 2002. Tropical browses: contents of phenolic compounds, in vitro gas production and stoichiometric relationship between short chain fatty acid and in vitro gas production. Journal of Agricultural Science 139:341-352.
Haigh, P.M., \& Hopkins, J.R. 1977. Relationship between oven and toluene dry matter in grass silage. Journal of Science Food Agriculture, 28(6):477-480.

Henrissat, B., Teeri, T.T., \& Warren, R.A.J. 1998. A scheme for designating enzymes that hydrolyse the polysaccharides in the cell walls of plants. FEBS Letters, 425(2):352-354.

Krishnamoorthy, U., Soller, H., \& Menke, K.H. 1991. A comparative study on rumen fermentation or energy supplements in vitro. Journal of Animal Physiology and Animal Nutrition, 65:28-35.

Kung, J.L, Treacher, R.J., Nauman, G.A., Smagala, A.M., Endres K.M., \& Cohen, M.A. 2000. The effect of treating forages with fibrolytic enzymes on its nutritive value and lactation performance of dairy cows. Journal of Dairy Science, 83:115-122.

Kuhad, R., Gupta, R., \& Singh, A. 2011. Microbial cellulases and their industrial applications. Enzyme Research. Article ID 280696:1-10.

Menke, K.H., Raab, L., Salewski, A., Steingass, H., Fritz, D., \& Schneider, W. 1979. The estimation of the digestibility and metabolizable energy content of ruminant feeding stuffs from the gas production when they are incubated with rumen liquor in vitro. Journal of Agricultural Science Cambridge, 93:217-222.

Menke, K.H., \& Steingass, H. 1988. Estimation of the energetic fed value obtained from chemical analysis and in vitro gas production using rumen fluid. Animal Research and Development, 28:7-12.

Muttoni, G., Palacios-Rojas, N., Galicia, L., Rosales, A., Pixley, K.V., \& Leon, N. 2013. Cell wall composition and biomass digestibility diversity in Mexican maize (Zea mays L) landraces and CIMMYT inbred lines. Maydica, 58:21-33.

Novel, P.S. 1998. Los incomparables agaves y cactus. Ed. Trillas. México. (In Spanish).p 211.

Nsereko, V.L., Morgavi, D.P., Rode, L.M., Beauchemin, K.A., \& McAllister, T.A. 2000. Effects of fungal enzyme preparations on hydrolysis and subsequent degradation of alfalfa hay fiber by mixed rumen microorganisms in vitro. Animal Feed Science and Technology, 88:153-170.

Onsori, H., Raza Zamani, M., Motalebi, M., \& Zarghami, N. 2005. Identification of over pro- 
ducer strain of endo-1,4-gluconase in Aspergillus species: Characterization of crude carboxymethyl cellulose. African Journal Bitechnology, 4:26-30. Robles Jimenez, L.E., Ruiz Perez, J.A., Nicolas, D.L., Chay Canul, A., Ramirez-Rivera, J.C., Villegas-Estrada, D., Vargas-Bello-Perez, E., \& Gonzalez-Ronquillo, M. 2019. Productive behavior in growing kid goats and methane production with the inclusion of chokecherry leaf (Prunus salicifolia). Tropical Animal Health and Production. doi:10.1007/s11250-019-02124-5

Salem, A.Z.M., Alsersy, H., Camacho, L.M., ElAdawy, M.M., Elghandour, M.M.Y., Kholif, A.E., Rivero, N., Alonso, M.U., \& Zaragoza, A. 2015a. Feed intake, nutrient digestibility, nitrogen utilization and ruminal fermentation activities of sheep fed Atriplex halimus ensiled with three developed enzyme cocktails. Czech Journal of Animal Science, 60:185-94.

Salem, A.Z.M., Ammar, H., Kholif, A.E., Elghandour, M.M.Y., \& Ortiz, L.B. 2015b. Effect of glucoamylase enzyme extract on in vitro gas production and degradability of two diets with $25 \%$ of corn or sorghum grains. Indian Journal of Animal Science, 85:183-88.

Salem, A.Z.M., Valdez, N.T., Olafadehan, O.A., Elghandour, M.M.Y., Barbabosa Pliego, A. \& Coyote, R.L. 2017. Influence of Aguamiel (Agave atrovirens) as a Natural Feed Additive on Cecal Fermentation Kinetics of Some Forage Species in Horse Feeding. Journal of Equine Veterinary Science, 48, 103-112. doi:10.1016/j.jevs.2016.08.012

Sang-Mok, L., \& Koo, Y.M. 2001. Pilot-scale production of cellulose using Trichoderma ressei Rut C-30 in fed-batch mode. Journal of Microbiology and Biotechnology, 11(2):229-233.

SAS, 2002. User's Guide: Statistics Ver 9.0. SAS Inst. Inc., Cary, NC, USA.

Settimi, C.C.S., Nassar, F.R., Ayres, O.M., Oliveira, F.A., Arnhold, E., and Ulhoa, C.J. 2013. Production, characterization and evaluation of fibrolytic enzymes on digestibility of forage maize. Ciencia Animal Brasileira, 14(4):426-435.

Snedecor, G.W., \& Cochran, W.C. 1994. 'Statistical Methods.' $8^{\text {th }}$ Ed. Iowa State University. Press, Ames.
Sun, Y., \& Cheng, J. 2002. Hydrolysis of lignocellulosic materials for ethanol production: a review. Bioresource Technology, 83(1):1-11.

Steel, R.G.D., Torrie, J.H., \& Dickey, D.A. 1997. Principles and Procedures of Statistics. In: $A$ biometrical approach, 3rd Ed. McGraw Hill Book Co, New York, USA.

Theodorou, M.K., Williams, B.A., Dhanoa, M.S., McAllan, A.B., \& France, J. 1994. A simple gas production method using a pressure transducer to determine the fermentation kinetics of ruminant feeds. Animal Feed Science and Technology, 48:185-197.

Togtokhbayar, N., Cerrillo, M.A., Rodríguez, G.B., Elghandour, M.M.Y., Salem, A.Z.M., Urankhaich, C., Jigjidpurev, S., Odongo, N.E., \& Kholif, A.E. 2015. Effect of exogenous xylanase on rumen in vitro gas production and degradability of wheat straw. Animal Science Journal, 86:765-771.

Valdes, K.I, Salem, A.Z.M., Lopez, S., Alonso, M.U., Rivero, N., Elghandour, M.M.Y., Domínguez, I.A., Ronquillo, M.G., \& Kholif, A.E. 2015. Influence of exogenous enzymes in presence of Salix babylonica extract on digestibility, microbial protein synthesis and performance of lambs fed maize silage. Journal of Agriculture Science Cambridge, 153:732-742.

Vallejo, L.H., Salem, A.Z.M., Kholif, A.E., Elghangour, M.M.M., Fajardo, R.C., Rivero, N., Bastida, A.Z., \& Mariezcurrena, M.D. 2016. Influence of cellulase or xylanase on the in vitro rumen gas production and fermentation of corn stover. Indian Journal of Animal Science, 86(1):70-74.

Van Soest, P.J., Robertson, J.B., \& Lewis, B.A. 1991. Methods for dietary fiber, neutral detergent fiber and non-starch polysaccharides in relation to animal nutrition. Journal of Dairy Science, 74:3583-3597.

Van Soest,. P.J. 1994. Nutritional Ecology of the Ruminant. $2^{\text {nd }}$ Ed. Cornell University Press. Ithaca. N.Y. USA.p 483.

Zsubori, Z.T., Pinter, J., Spitko, T., Hegyi, Z., \& Marton, C.L. 2013. Yield and chemical composition of plant parts of silage maize (Zea mays L) hybrids and their interest for biogas production. Maydica, 58:34-41. 